\title{
Optimization of The Role of State Storehouse for Seized Goods (RUPBASAN) Expansion of The Authority in The Perspective of Integrated Criminal Justice System
}

\author{
Irma Cahyaningtyas ${ }^{1 *}$ \\ ${ }^{1}$ Faculty of Law, Diponegoro University, Semarang, Indonesia
}

\begin{abstract}
On the investigation process one of it forced effort by the investigator, namely seizure. Seized goods are saved $\mathrm{n}$ maintenance in The Role of State Storehouse for Seized Goods which namely RUPBASAN The problem of this paper are first, How is the implementation of authority process of the seized goods of state and the state booty in RUPBASAN; second, How is expansion of authority of RUPBASAN at the future. The method is used a normative juridical method which statute approach. The results show that the authority of RUPBASAN as effort to carry out its main duties are as follows: administering; conducting maintenance and transfer of State's Confiscated and Seized Objects; conducting security and management of RUPBASAN; conducting business correspondence and filing but there is a facts in the RUPBASAN especially in management and maintenance of seized and spoiled goods of the state. Penal reforms of RUPBASAN are need to be realized which are not just to management and maintenance of seized and spoiled goods but it can also to strengthening of the RUPBASAN duties and authorities to extended to give the authority to auction the goods.
\end{abstract}

\section{Introduction}

Indonesia is a Nation of Laws. One of the Nation's efforts in implementing the policy is by creating and implementing regulations. In order to realize the development, the restructure of State Assets is very necessary. This is due to the increasing number of criminal acts committed in a systematic way that resulted in the government's disadvantage in a very large amount. For that, an action is needed to save the state assets.

One of the government's efforts is conducting sequestration that can be done by the Investigator. Sequestration can be made against objects used to commit crimes or objects resulting from a criminal offense committed by perpetrators of crime. The purpose of sequestration is for the sake of evidentiary primarily intended as evidence in trial, for without

\footnotetext{
${ }^{*}$ Corresponding author : irmafjr83@gmail.com
} 
such evidence, the case cannot be brought to the Court. Therefore, in order for the case to be completed with the evidence, the Investigator commits the sequestration to be used as evidence in the investigation, in the level of prosecution, and the level of judicial hearings [1].

In order to maintain the quality and quantity of Seized Objects, there is a storage place which is called the Depository Storage of State Seized Object namely RUPBASAN. Talking of Criminal Justice Process according to the community, it must be identical with the police, prosecutor, judiciary, and correctional institutions. The different things when talking about the RUPBASAN not all people know. RUPBASAN is used for storing the Seized Objects until obtaining a court decision with permanent legal force. Based on the provisions contained in Article 44 paragraph (1) Seized goods shall be kept in a state storehouse for seized goods; paragraph (2) The storage of seized goods shall be conducted in the best possible manner and the responsibility therefore shale rest with the official authorized in accordance with the stage of examination in the criminal justice process and the use of said goods by any person whomsoever shall be forbidden.

Based on field facts, function application function of RUPBASAN are not running optimally so it needs to be analysis pattern function of RUPBASAN.

\section{Objective of the study}

This study aims to investigate how is the implementation process of seized goods in RUPBASAN at this time and also how is expansion of authority of RUPBASAN at the future.

\section{Methodology}

This study uses a normative juridical method with statute approach[2] based on Indonesian Criminal Code Procedures and regulations related with RUPBASAN and based on field fact at this time and also to analysis authority of RUPBASAN need to be realize.

\section{Discussion}

\subsection{Implementation of Authority Process of The Seized Goods of State and The State Booty in RUPBASAN}

Evidence in a criminal case may be seized by the Investigator for the sake of Evidentiary in the level of investigation, prosecution and hearing in the Court. To carry out its main tasks, RUPBASAN has the following functions. There are first, to administering the State's Confiscated and Seized Objects; second, to conducting maintenance and transfer of State's Confiscated and Seized Objects; third, to conducting security and management of RUPBASAN; and fourth to conducting business correspondence and filing.[3]

In the perspective of Criminal Justice System conceptually, the birth of RUPBASAN institution as an important institution in the Act No. 8 Year 1981 regarding Indonesian Criminal Code Procedures is based on two important principles. Firstly, the principle of functional differentiation. This principle requires that in the law enforcement there will be no "overlapping" in the law enforcement process. Importantly, the concentration of an authority against one institution is "forbidden" carried out. In the context, the RUPBASAN is present to provide collateral for seized goods as a form of realization of "legal certainty" to the seized goods.

The other principle is the principle of coordination, in the form of the division of duties and authorities institutionally in the corridor of the relation between law enforcement 
agencies that work together and at the same time the establishment of a checking system between agencies. If it is associated with the position of the sub system in Criminal Justice system, the role of RUPBASAN is very small. Different from all sub system of Criminal Justice System, each duties and authorities are regulated in the Act No.8 Year 1981 regarding Indonesian Criminal Code Procedures in detail and in the law concerning the agency itself.

Legislation regarding the position of RUPBASAN:

1. Criminal Code Procedure in particular the provisions of Article 44 paragraph (1)

2. Decree of the Ministry of Justice of the Republic of Indonesia Number M.04.PR.07.03 of 1985 regarding Organization and Working Procedures of State Detention Home and State Storehouse for Seized Goods, dated September 20, 1985

3. Regulation of the Ministry of Justice and Human Rights Number 16 of 2014 regarding Management Procedures of State Seized Goods and Seized State Assets in Rupbasan.

4. Law Number 22 of 2009 regarding Traffic and Road Transportation. In this law, several articles regulate where the seized goods of traffic crime shall be kept.

5. Joint Regulation of the Head of Indonesian National Police, Attorney General, Corruption Eradication Commission, Ministry of Justice and Human Rights, Supreme Court, and Ministry of Finance of the Republic of Indonesia. Number 2 of 2011; No. Kep/259/A/JA/12/2011; No. KEPB-10/01-55/11/2011; No. M.HH-10.HM.03.02 of 2011; No. 199/KMA/SKB/XII/2011; No. 219/PMK.04/2011 regarding the Synchronization of Management System of Basan and Baran.

6. Regulation of the Head of Indonesian National Police Number 8 of 2009 regarding Principle Implementation and Standard of Human Rights in the implementation of Indonesian National Police's duties.[4]

Empirical facts in the RUPBASAN often arise problems in the management and maintenance of seized and spoiled goods of the state. So that frequently there is the authority abuse, safekeeping of seized goods that is too long and even accumulate and often forgotten by prosecutors as executives. This, of course, can have an effect on the maintenance process is not maximally biased especially if the seized goods have been deposited for years.

According the Act No. 8 Year 1981 regarding Indonesian Criminal Code Procedures in Article 44, the scope of the provisions is essentially aimed at seizing goods, whether they are in the form of corpora delicti or subject to criminal acts (for example: goods stolen, deceived, etc.), resulting from criminal acts (counterfeit money, luxury car or medical device resulting from corruption, etc.), or goods which are used to commit criminal acts instrumenta delicti, can be maintained and used properly according to the stages of examination, both for the purposes of investigation, prosecution and verification of hearing. If seen from efficiency and time, RUPBASAN should be responsible for state confiscated and seized goods as an object. [5]

If the state confiscated and seized goods are stored for too long, RUPBASAN will send a letter to the judiciary to ask about the fate of the case related to the seized goods, especially if it turns out that the case has already the permanent legal force or inkracht then the position of the seized goods can be auctioned.

Talking about the auction can be a new problem because the auction is not the duty and authority of the RUPBASAN. RUPBASAN is only a place of deposit counter and the officer only takes care until the goods are taken back. So based on that empirical facts, government needs to effort to carry out penal reforms to expand authority of RUPBASAN. 


\subsection{Expansion of Authority of RUPBASAN At The Future}

Penal reforms of RUPBASAN are need to be realized. This matter can be analysis used by legal system theory. As stated by Lawrence M. Friedman, the aspects in the law, as follows:[6]

1. The aspect that is called the structure. It is the institution that is established by the legal system, such as the district court, the administration court with the function to support the legal system itself. The structure component supports the provision of service and law on a regular basis;

2. The substance component, the legal norms, regulations, decisions, and so on are used by the law enforcer or those who are regulated by law;

3. The cultural law component. It is composed of ideas, attitudes, expectations, and opinion on the law. The legal culture is categorized into internal legal culture (owned by lawyers and judge) and external culture (for the people in general).

Based on legal system theory, the thing that needs to be done is that the rules shall be immediately codified regarding the strengthening of RUPBASAN institution through the following matters first, making general rules by classifying the rules regarding the existing RUPBASAN. Its needed for strengthen the position of RUPBASAN, especially related to the RUPBASAN's duties and authorities, the legislators shall make the laws specially regulate the RUPBASAN institutionally; second, creating professional enforcement officers who are authorized to carry out their duties and functions in the management and maintenance of state's confiscated and seized goods by providing education and training, providing facilities and infrastructure to support work[7] and supported by an appropriate budget. In fact, budget to maintenance of Objects which are stored at RUPBASAN or outside RUPBASAN are minimal. As stated by Eva Achjani Zulfa[8] budget for maintenance of objects are about one million rupiahs every month whereas the objects treated are thousands.

Another things that need to reform are to strengthening of the RUPBASAN duties and authorities which are not only a storage place and management of seized and spoiled goods through the administration of seized goods and physical maintenance of the seized goods but are extended to give the authority to auction the goods which are deposited where the case has already inkracht so that in every RUPBASAN will not occur accumulation of goods. When viewed from the cost and time efficiency the government should issue the rules regarding the management of state seized goods, and at the same time provide the authority to auction the state seized goods so that the execution of a state deposit counter can be carried out quickly. This is aimed at the seized goods so that the value does not go down, then they can conduct an auction as soon as possible. Thus, the potential for state losses on the depreciation of the value of seized goods is not big; and the last it is necessary to have the RUPBASAN bureaucracy management in one door so that there shall be a database system that contains the total amount of goods and shall be updated regularly because basically the goods shall be stored and managed in the RUPBASAN.

\section{Conclusion}

RUPBASAN is one of the institutions which is engaged in law enforcement in Indonesia has heavy duty. To realize the ideals of the Indonesian Nation's laws and at the same time to realize the law, then the role of law enforcement institutions is very important, especially in carrying out their duties and functions relating to the law enforcement.

Penal reform in RUPBASAN must be realized. That things in a structure component which is making general rules to strengthen the position of RUPBASAN; in a substance component are creating RUPBASAN's professional enforcement officer management and 
maintenance of seized and spoiled goods, strengthening of the RUPBASAN duties and authorities to extended to give the authority to auction the goods; in a culture component is strengthening of RUPBASAN at the community as a sub system of criminal justice process.

\section{References}

1 S. Makarao, M. Taufik, Hukum Acara Pidana (Dalam Teori dan Praktek) (Ghalia Indonesia, Jakarta, 2004)

2 Y. A. Fajar, Mukti, Dualisme Penelitian Hukum Normatif dan Empiris, 1st ed. (Pustaka Pelajar, Yogyakarta, 2010)

3 A. Hamzah, Hukum Acara Pidana Indonesia (Sinar Grafika, Jakarta, 2006)

4 H. Nugroho, Optimalisasi Pemanfaatan Aset Benda Sitaan Negara (Studi Tentang Penyelamatan Aset-Aset Tindak Pidana Korupsi), Prociding Semin. Nas. Pengemb. Sumber Daya Perdesaan dan Kearifan Lokal Berkelanjutan, (2017)

5 M. P. Djapai, Pengelolaan Benda Sitaan Menurut Pasal 44 KUHAP, Lex Crim., VI, pp. 37-38, (2017)

6 L. M. Friedman, The Legal System : A Social Science Perspective (Russel Sage Foundation, New York 1975)

7 A. Sanusi, Tata Kelola Benda Sitaan Negara Pada Rumah Penyimpanan Benda Sitaan Negara, J. Ilm. Kebijak. Huk., 12 (2018)

8 E. A. Zulfa, Barang Sitaan Menumpuk, Ongkos Perawatan Minim (2008). 